\title{
The SGP - Faulty by Design or Made Faulty by Politicians? An Assessment Based on a Simulation Model $^{1}$
}

\author{
Šárka Horáková2, Robert Jahoda ${ }^{3}$
}

\begin{abstract}
By joining the European Monetary Union (the "EMU"), member countries lost the ability to use monetary policy as a tool for macroeconomic regulation. The attention was then focused on regulation of fiscal policy and Stability and Growth Pact (the "SGP") was the instrument agreed upon. The states of the EMU have agreed to meet the $3 \%$ of GDP requirement for the maximum annual public budget deficit. Based on evolution of public debt in member countries, we can say that the SGP has failed as a tool for fiscal discipline. In this paper, we answer the question of whether the failure was due to the incorrect concept of the SGP or whether the development of the debt was affected more by arbitrary disrespect of the agreed rules. The two reasons mentioned above are interdependent. To separate them, we construct a dynamic model of EU countries' public debt. By using real data, we simulate the potential values of public debt in a situation where the SGP rules have been respected in recent years. Comparing the results for the potential debt given by simulation of the model with the current real values, we are able to quantify the impact of non-compliance for each country. The initial results indicate that there are both EU states where non-compliance led to a negligible increase in public debt - up to 7\% of GDP - and other states where this factor caused the growth of public debt by more than $30 \%$ of GDP.
\end{abstract}

Key words: Fiscal policy, primary balance, public debt, European Monetary Union, Stability and Growth Pact, fiscal sustainability

JEL Classification: C63, E62, H62, H63

\section{Introduction}

Establishment of procedures for the functioning of the single currency and the European Monetary Union ("EMU") was one of the motives of the Maastricht Treaty. By joining the EMU, member countries surrendered one part of their sovereignty and entrusted monetary policy to the European Central Bank (ECB). Fiscal policy remained to them as a tool for macroeconomic stabilization. Coordination of fiscal policies is necessary to

\footnotetext{
${ }^{1}$ The authors are thankful to the Grant Agency of Masaryk University for the grant No. MUNI/A/0784/2013.

${ }^{2}$ Masaryk University, Faculty of Economics and Administration, Department of Public Economics, Lipová 41a Brno 62100, sarka.horakova@econ.muni.cz

${ }^{3}$ Masaryk University, Faculty of Economics and Administration, Department of Public Economics, Lipová 41a Brno 62100, robert.jahoda@econ.muni.cz
} 
ensure functioning of the common currency and the Stability and Growth Pact (SGP) was drawn up as a tool for fiscal discipline. It was expected that the Maastricht criteria together with the SGP would ensure fiscal discipline in the EU. However, as we have seen in the recent years, these expectations have not been met. Von Hagen and Wolff (2006) claim that the introduction of the SGP together with the Excessive Deficit Procedure (EDP) caused the use of "creative accountability" whereby member countries falsified the statistics or used non-standard fiscal operations to meet the reference values.

The financial crisis, which has grown into a debt crisis in the euro area, clearly shows how important it is to pay more attention to the state of public debt. Despite the Maastricht criteria and the SGP, many states have failed to reduce the value of their debt to a sustainable level (Van Nieuwenhuyze 2013). Stoian and Alves (2012) also show in their study that the euro area does not follow any fiscal policy that would be compatible with the requirements of the SGP.

One of the consequences of the debt crisis is that risk can be determined for each country separately, while bonds are denominated in the common currency. This contradicts the principles of the EMU which were established in the 1990s (Buiter 2006). Economy of the member countries is very heterogeneous and, furthermore, we cannot talk about fiscal federalism in the EU. The euro seems overvalued for the southern European countries (including France) and underestimated for countries in Northern Europe, especially Germany (Coudert 2013; Duwicquet et al. 2013). Financial markets may decide to refuse a loan to some countries, simply because the operation would be too risky. Consequently, heavily indebted countries may find themselves close to default.

The concept of fiscal sustainability can be defined in various ways. Blanchard et al. (1990), for example, state that evolution of the debt/GDP ratio depends on the following factors: primary deficit reflecting the current spending, inherited level of debt/GDP from past times and the difference between the real interest rate and the economic growth. A sustainable fiscal policy occurs when the ratio of debt/GDP after some excessive deflection returns to its original value, i.e. the initial value before the significant bulge in the trend. Afonso (2005) simply claims that in order to achieve a sustainable fiscal policy, the government deficits have to be compensated for by deficit surpluses in the future. The ECB (2012, p. 55) notes that fiscal sustainability is "a country's ability to service all accumulated government debt at any point in time". Deviations from the equilibrium are permitted; the important point is that the level of the debt remains stationary or decreases in the long run. According to Collignon (2012, p. 7), the concept of fiscal sustainability is associated with the concept of dynamic equilibrium. Such equilibrium does not necessitate any important changes in fiscal policy and ensures long-term financial stability, i.e. the markets borrow to cover needs of the state. Temporary deviations from the sustainable level are permitted if they are fully corrected. To ensure debt sustainability in the long run, it is necessary to follow fiscal rules that are able to guarantee such a state. Afonso and Rault (2010, p. 11) add that to describe the fiscal policy as sustainable, the level of debt has to converge to zero in infinity and at the same time it cannot rise faster than the real interest rate.

Such rules have been established in the SGP specifically to ensure the sustainable fiscal discipline of the signatory countries. The value of the $60 \%$ debt/GDP ratio was determined based on the average of the members, and the $3 \%$ threshold for the deficit/GDP 
ratio is based on a simple dynamic model for public debt. According to De Grauwe (2003, p. 2), "it is well known that the $3 \%$ deficit norm will ensure that the $60 \%$ debt ratio can be kept constant provided the nominal growth of GDP happens to be 5\%". It is necessary to respect this value to avoid constant growth of debt and the snowball effect.

In our paper, we use the simple public debt dynamic model to answer the question of whether the failure was due to incorrect concept of the SGP or whether the development of the debt was affected more by arbitrary disrespect of the agreed rules. The two reasons mentioned above are interdependent. To separate them, we construct a dynamic model of EU countries' public debt. Using real data, we simulate the potential values of public debt in a situation in which the SGP rules have been respected in recent years. Comparing the results for the potential debt given by the simulation of the model with the current real values, we are able to quantify the impact of non-compliance for each country.

Stoian and Alves (2012) use a similar model to calculate the level of government surplus that would be necessary to stabilize the public debt. Stoian (2011) believes that economic crisis may have been instigated due to improper fiscal policy. He uses a dynamic model of debt to determine whether the conduct of fiscal policy is vulnerable or not. Afonso (2005) uses the model of a stationary test to determine fiscal sustainability of all the eurozone member countries and, like most authors, he agrees that implementation of fiscal policy is not sustainable. Using this model, Izák (2009) confirms that a government that runs a budget deficit faces significantly higher costs of borrowing. Van den Noord (2010) attempts to quantify the costs of the financial crisis and the impact it has on the sustainability of public finance.

\section{The Stability and Growth Pact and Its Evolution}

The SGP is an essential tool established in order to sustain sound public finances within the EU. The Maastricht Treaty of 1993 is the principal document for the SGP's constitution. It provides that - as part of the economic and monetary integration - EU member states will form European economic and monetary union (hereinafter referred to as the EMU) and adopt the euro as a single currency. Furthermore, the fulfillment of the requirement to follow commonly known rules is a necessary prerequisite here: the GDP share of public deficit should not exceed 3\%, and the GDP share of public debt should not amount to more than $60 \%$. As stated by Fischer et al. (2006), Germany in particular was deeply concerned that these criteria were insufficient, and feared that failure to follow the criteria of budgetary equilibrium would cause inflation to rise, as was the case in the inter-war period. The stability of the common currency would thus be threatened. Furthermore, this brought about the conflict of monetary policy, assigned to the newly born European Central Bank, and fiscal policy, which remained the competence of individual nation states. While the Maastricht criteria served as an indicator for EMU accession, what was missing was any tool to enforce the observation of the rules by the states already within the EU. This is why Germany initiated that the Stability and Growth Pact be created. The pact was adopted at the Amsterdam European Council summit in 1997. It consists of three documents:

- Resolution of the European Council on the Stability and Growth Pact Amsterdam, June 17, 1997 (1997); 
- Council Regulation (EC) No. 1466/97 (1997);

- Council Regulation (EC) No. $1467 / 97$ (1997).

The aim of the SGP is to maintain the public finance deficit within $3 \%$ of GDP and the public debt under $60 \%$ of GDP. To achieve these objectives, the SGP consists of two mechanisms: a preventive arm and a corrective arm.

As its name implies, the preventive mechanism aims to ensure absence of excessive deficits. Therefore, the EU member states submit their stability (for eurozone members) and convergence (for non-eurozone members) programmes. These programmes are then evaluated by the European Commission which subsequently makes recommendations to the Council of the European Union. The Council then adopts the opinion. The preventive mechanism is based on two measures. Based on recommendations by the Commission, the Council is authorized to give an early warning when preventing an excessive deficit. Still, if the limit is exceeded, the sanction mechanism, or more precisely the Excessive Deficit Procedure (EDP), should come into play. This is known as the corrective arm. The pact commenced use only after finishing the third stage of economic and monetary integration in 1999, the year in which the euro was adopted.

Its suitability as a tool to sustain fiscal discipline within the EU has been questioned since the beginning of its implementation. Even the two basic criteria were considered as arbitrary and insufficiently supported by theoretical foundations (Calmfors 2005). Wenzel et al. (2004) argue that the Stability and Growth Pact does not allow an adequately flexibly response to economic fluctuations, especially if fiscal policy is the only instrument suitable for their mitigation. Buti and Martinot (2000) add that there is a lack of prevention of pro-cyclical expenditure increases or tax reduction during growth periods.

Alesina and Giavazzi (2002) object to the fact that states with a low (Portugal) and high debt level (Greece or Italy) are treated equally. An example could be the early warning for Ireland in 2001. Ireland was punished because its predicted growth was higher than its real growth. The EDP was launched despite the non-existence of an excessive deficit. The authors take the view that the mechanisms of the SGP should primarily target the states with high debt ratios, make them reduce their public debt and strive to restore stability of public budgets. They also criticize the SGP for undue collegiality. They point out that the mechanisms are used only with minor states, whereas for larger states like Germany, France or Great Britain, they remain a mere formal admonition since all procedures are blocked by the qualified majority within the Council. Buti et al. (2003) are concerned with the same problem when they argue that enforceability is the weakest point of the SGP. This issue is connected with the event of 2002 in which the public deficit indicator was exceeded by two founding EU countries, Germany and France. That is why the Commission suggested that the EDP be initiated, which was, however, rejected by the Council in both cases. It may be assumed that the Council's decision was driven by political reasons since both countries remain influential when enforcing their interests.

Nevertheless, employment of "creative accounting" is probably the most significant problem. Governments deliberately distort their statistical data to avoid the EDP (von 
Hagen and Wolff 2006, p. 9). It is fair to say that the SGP is not to blame here, as data alteration was voluntary decision of the states, after all.

In 2005, the Council prepared a proposal for SGP reform, which was approved. The reform introduced some new elements, but none of them represented a fundamental systemic change. Schuknecht et al. (2011, p. 10) argue that it brought "greater discretion, leniency and political control into procedures. The strictness of the $3 \%$ limit and the time frame for correcting excessive deficits were relaxed, while procedural deadlines were extended. The greater complexity of the rules made monitoring by markets and the public more difficult."

The biggest deficiency of the SGP - disrespect of the agreed rules, lack of consistency in the application of sanctions and weak enforcement provisions - were not dealt with even with the reform. In 2005, ECOFIN expressed its uneasiness towards the frail institutional framework and the results of the reform.

Considering the above, it is no surprise that Schuknecht et al. (2011, p. 10) call the period 1999-2007 as "wasted good times". The member countries should take advantage of favourable economic development and reduce their deficits or create surpluses. However, neither happened. Hauptmeier et al. (2010, p. 9) describe the ongoing fiscal policy as "broadly relaxed".

As the recession struck in 2008, the situation further deteriorated and in 2009-2010, none of the euro area countries was capable of drawing up a balanced budget. During 2010, all EU countries, whether euro area members or not, fully faced the consequences of crisis. As a response to the crisis, national governments adopted several measures to mitigate the impact of the crisis and start the economy. At the same time, it was necessary to take action at the European level and restore credibility of the financial framework in the European Union. The efficiency of the SGP was underestimated and the coordination of the fiscal discipline had to be strengthened.

In autumn 2010, the Council signed the project of the so-called European Semester. It aims to provide a structural framework within which the member states will coordinate their budgetary and economic policies in accordance with the Stability and Growth Pact and the Europe 2020 strategy. As a result, the states are provided with more space for implementing the recommendations of the Council and the European Council; on the other hand, such policy recommendations are given to the states before the approval of their national budgets (European Commission, 2013).

Euro Plus Pact (European Union Law 2011 Is another agreement strengthening fiscal discipline. It aims to foster the economic pillar of monetary union, improve quality of the coordination of economic policies and boost competitiveness, which will result in greater convergence. Annual measures will be implemented in stability and convergence programmes to establish a connection between the Euro Plus Pact, the SGP and the European Semester. A major contribution of the Euro Plus Pact is to provide an obligation to introduce the SGP fiscal rules in the member states' legislation, which, in fact, gives rise to budgetary responsibility.

So far, the latest strengthening of the SGP is represented by the signing of the Treaty on stability, coordination and governance in the economic and monetary union in late Jan- 
uary 2012, known as the European Fiscal Compact (see European Commission 2012). The signature commits euro area members as well as all the remaining countries, with the exception of the Czech Republic and United Kingdom. The treaty aims to strengthen budgetary discipline at the national level. The maximum medium-term structural deficit is set to $0.5 \%$ of GDP (or $1 \%$ of GDP under specified conditions). The treaty also provides that the European Court of Justice will act as an arbitrator. In the case of rule infringement, the court will have the right to fine member states.

\section{Methodology and Data}

The following part of the paper presents a simulation model to assess the impact of deviating from the terms agreed in the SGP. When constructing the model, we follow the literature on fiscal sustainability, especially the works of Blanchard et al. (1990) and Izák (2009) already mentioned. This chapter also contains a brief description of the data used in the model.

We use two basic indices for the variables. The upper index $t$ always marks a year for which the value is calculated or simulated. We have two possibilities when it comes to the lower index. In the first case, the lower index of variables is missing; in this case, the variable is calculated from the data available (see the end of this section). In the second case, the lower index $\mathrm{S}$ is used to describe the simulated variable which is determined as described below.

The root of model (1) is based on the equation of time for the public debt which stipulates that the level of public debt in the current year (marked as $B^{t}$ ) is equal to the level of debt in the previous year and this year's change in debt.

Ideally, the change in this year's debt (equation 2) is equivalent to the level of public deficit in a given year $\left(D^{t}\right)$. Afonso (2005) draws attention to the fact that the transfer of public deficit into debt is not necessarily time-consistent within one year. He also notes that the government policy can raise the debt in extra budgetary ways. Eurostat (2013) discusses stock-flow adjustment (SFA) and states that it is the difference between the change in the stock of government debt and the flow of the annual deficit/surplus. Since 2009, Eurostat has distinguished SFA into the following components: net acquisition of financial assets, debt adjustment effects and statistical discrepancies. The importance of SFA has been emphasized many times because it can highlight data quality problems. It has been argued that since great attention is paid to the deficit under the current EU multilateral fiscal surveillance (EDP and Stability and Growth Pact), governments may have an incentive to underreport their deficits by reporting transactions under SFA. Accordingly, we can draw the conclusion that the line between SFA and "creative accounting" is very thin and unclear.

Therefore, we introduce and compute the variable which captures all situations in which the growth of public debt in the reference year is different from the size of the public deficit. At the same time, we could not make use of the Eurostat data on SFA since data of the required quality are available only from 2009.

$$
\begin{aligned}
& B^{t}=B^{t-1}+\Delta B^{t} \\
& S F A^{t}=\Delta B^{t}-D^{t}
\end{aligned}
$$


The public deficit (in equation 3a) can be expressed as the sum of the primary balance $\left(P D^{t}\right)$ and the interest on public debt $\left(I B^{t}\right)$. At the same time, we follow the standard practice of using capital letters to indicate the nominal values of the monitored variables and lower-case letters to denote their share in the gross domestic product (see equation $3 b)$.

$$
\begin{gathered}
D^{t}=P D^{t}+I B^{t} \\
d^{t}=\frac{D^{t}}{G D P^{t}}
\end{gathered}
$$

In the real economy, the amount of interest on public debt depends on a combination of instruments used by the government to finance the debt and their cost. We use a simplified relationship in the model (equations $4 \mathrm{a}$ and $4 \mathrm{~b}$ ) to show that the amount of interest in a given year depends on the amount of the debt at the end of the previous year and the implicit interest rate $\left(r^{t}\right)$ of the debt. Equation 5 calculates the annual real growth of the gross domestic product $\left(y^{t}\right)$ from data on GDP at constant (2005) prices $\left(G D P_{*}\right)$.

$$
\begin{gathered}
I B^{t}=r^{t} * B^{t-1} \\
r^{t}=\frac{B^{t-1}}{I B^{t}} \\
y^{t}=\frac{G D P_{*}^{t}}{G D P_{*}^{t-1}}-1
\end{gathered}
$$

The rules of the SGP assume that the public deficit in the medium term has to converge to zero and must not exceed 3\% of GDP in a given year. While we cannot clearly interpret what "the public deficit in the medium term has to converge to zero" means, the $3 \%$ limit is easily controllable. We use therefore the $3 \%$ limit rule which was set at the beginning of implementation of the SGP. If the conduct of budgetary policy does not respect this limit, we cannot blame the approved rules of the SGP for the consequences. Equation 6 therefore provides a basic assumption on which the model stands, namely that the value of the public deficit in each year should be lower than $3 \%$ of GDP.

As such, we simulate this policy in the form of the ratio indicator $\left(d_{s}^{t}\right)$ or nominal indicators $\left(D_{S}^{t}\right)$ in equation 7 . The $\mathrm{S}$ indicates that these values are simulated to satisfy the rules of the SGP, and at the same time not to reach worse values than those achieved with the actual policy.

$$
\begin{aligned}
d_{s}^{t} & \leq 3 \% \\
d_{s}^{t} & \leq \frac{D_{s}^{t}}{G D P^{t}}
\end{aligned}
$$

Assuming that the simulated policy of the state in each year complied with the rules of the SGP and would not achieve worse values than real policies, it is expected that the simulated level of public debt $\left(B_{S}^{t-1}\right)$ should be reduced, or at least be at the same level as the actual debt. In this situation, however, the level of simulated interest on the public debt $\left(I B_{S}^{t}\right)$ was also on a lower or at the same level as the actual level of public debt. We assume (see equation 8) that the simulated level of interest on public debt is due to the simulated level of public debt and the amount of the implicit interest rate.

$$
I B_{S}^{t}=r^{t} * B_{S}^{t-1}
$$


The simulated level of public deficit in a given year is determined by simulated interest on the public debt and the amount of simulated primary deficit (equations $9 \mathrm{a}$ and $9 \mathrm{~b}$ ). If the government succeeds in maintaining the public deficit below the reference value of $3 \%$ of GDP, there is no reason for the simulated primary balance to be different from the real state. However, if the budgetary policy of the government does not comply with the rules of the SGP, we simulate the primary balance in such a way that it reaches, together with the simulated interest on public debt, the worst permissible level $-3 \%$ of GDP. Another constraint for the simulated primary balance asserts that it cannot be worse than the actual primary balance (such a term is described in equation 9a).

$$
\text { if }\left(d^{t} \leq 3 \% ; P D_{S}^{t}=P D^{t} ; P D_{S}^{t}=\operatorname{MIN}\left(P D^{t} ; 3 \% * G D P^{t}-I B_{S}^{t}\right)\right)
$$

In this situation, overall deficit is equal to the sum of simulated primary balance and simulated interest on public debt. This deficit never exceeds $3 \%$ of GDP in the given year and is in accordance with the rules of the SGP. The rules, however, allow an exception for the $3 \%$ reference limit in the case in which the real GDP growth is negative 0.75\% or lower (see Article 2 (3) in European Commission (1997a) and the corresponding explanation in European Commission (1997b)). For such situations, the model allows the simulated value of public budget deficit to equal the actual value of the primary balance and simulated interest on the public debt (this exception is described in equation $9 b)$.

$$
\text { if }\left(\left(y^{t}<-0,75 \%\right) ; D_{S}^{t}=P D^{i}+I B_{S}^{t} ; D_{S}^{t}=P D^{i}+I B_{S}^{t}\right)
$$

Equations 1 and 2 are used to describe the decomposition of the actual government debt; equations 10 and 11 then return to compose the simulated level of debt. Equation 10 therefore states that the simulated increase in public debt is equal to the simulated deficit and the "time discrepancies" that we have excluded in equation 2 from the other calculations. Finally, equation 11 describes the simulated amount of debt at the end of the budget period as equal to the simulated value of the debt at the beginning of the period and the simulated growth of public debt in the given period.

$$
\begin{aligned}
& \Delta B_{S}^{t}=D_{S}^{t}+S F A^{t} \\
& B_{S}^{t}=B_{S}^{t-1}+\Delta B_{S}^{t}
\end{aligned}
$$

In order to perform the calculations mentioned above, it is necessary to set the period from which the quality of the budgetary policy of the government will be followed up. Due to the date of the introduction of the Stability and Growth Pact and the availability of the necessary data for each country, the first simulation of the public deficit is for the year 1996. At the same time, we set the same level for simulated and actual indebtedness in 1995 (equation 12). The most recent data in our model obtained from the Eurostat server are for the year 2012. We evaluate the quality of the fiscal policy of each country in the past 17 years when we compare the amount of the real and the simulated level of public debt (equation 13). For reasons of comparability, we always use a GDP ratio.

$$
\begin{gathered}
B_{S}^{1995}=B^{1995} \\
A 1_{j}=\frac{B_{S}^{2012}-B^{2012}}{G D P^{2012}}
\end{gathered}
$$


It should be said that our simulation is based on several assumptions. We would like to mention two of them briefly. First of all, our simulation of public deficit change does not account for the fact that a lower public deficit may have an impact (from a Keynesian view) on the level of economic output. It is possible that lower governmental expenditure decreases the aggregate demand and therefore decreases the country's GDP. At the same time, it might be said that a lower level of public debt implies lower tax quota in the near future with a positive impact on the economic output. The second assumption deals with implicit interest rate $\left(r^{t}\right)$. The cost of the public debt is determined by many factors, one of which is the credibility of a country's public finance. Such credibility is ceteris paribus connected to the level of public debt and accountability and the transparency of the fiscal policy. One may therefore say that a transparent fiscal policy that involves adherence to the agreed rules would induce interest rate premiums from the capital market in a certain period of time, which lowers the public debt cost. This paper does not take the possible premiums of simulated responsible fiscal policy into account, though.

Table 1: List of Eurostat Data Utilized in the Simulation

\begin{tabular}{|c|c|c|c|c|c|c|}
\hline \multirow{2}{*}{$\begin{array}{l}\text { Code in } \\
\text { Equations }\end{array}$} & \multicolumn{4}{|c|}{ EUROSTAT } & \multirow[b]{2}{*}{ Extracted on } & \multirow{2}{*}{$\begin{array}{l}\text { Used in } \\
\text { equation }\end{array}$} \\
\hline & $\begin{array}{l}\text { Database } \\
\text { code }\end{array}$ & ESA95 Code & Unit & Last update & & \\
\hline GDP & nama_gdp_c & B1GM & MIO_NAC & $\begin{array}{c}\text { January 11, } \\
2014\end{array}$ & $\begin{array}{c}\text { January 13, } \\
2014\end{array}$ & $3 b$ \\
\hline B & gov_dd_edpt1 & GD & MIO_NAC & $\begin{array}{c}\text { January } 8 \\
2014\end{array}$ & $\begin{array}{c}\text { January 13 } \\
2014\end{array}$ & $1,2,4 a, 4 b$ \\
\hline$D$ & gov_dd_edpt1 & EDP_B9 & MIO_NAC & $\begin{array}{c}\text { January } 8 \\
2014\end{array}$ & $\begin{array}{c}\text { January 13 } \\
2014\end{array}$ & $2,3 a, 3 b$ \\
\hline PD & gov_dd_edpt1 & PRIMBAL & MIO_NAC & $\begin{array}{c}\text { January 8, } \\
2014\end{array}$ & $\begin{array}{c}\text { January 13 } \\
2014\end{array}$ & $3 a$ \\
\hline \multirow[t]{3}{*}{ IB } & gov_dd_edpt1 & EDP_D41 & MIO_NAC & $\begin{array}{c}\text { January 8, } \\
2014\end{array}$ & $\begin{array}{c}\text { January 13, } \\
2014\end{array}$ & $3 a, 4 a, 4 b$ \\
\hline & \multicolumn{4}{|c|}{ United Nation Data } & & \\
\hline & & SNA Code & Unit & Last update & & \\
\hline GDP* & & 9 & NAC & $\begin{array}{c}\text { December } \\
16,2013\end{array}$ & $\begin{array}{c}\text { February } 25 \\
2014\end{array}$ & 5 \\
\hline
\end{tabular}

As has been mentioned already, the model is based on Eurostat data for the period 1995-2012 and assesses the quality of budgetary policies of national governments in 1996-2012. We are limited to the year 1995 because it is the first year for which the data are available in the Eurostat database. At the same time, the year 1995 lies between the year of the adoption of the Maastricht Treaty (1993), which stipulated the need to monitor fiscal criteria, and the year of the adoption of the Stability and Growth Pact (1997) which defined the Excessive Deficit Procedure. Unfortunately, not all the data are available in the 1995-2012 time series. The first data are available for Romania in 1996, for Bulgaria in 1998 and for Denmark, Poland and Greece in 2000. In these cases, the evaluation period of fiscal policy is shorter. In the model, the following data from the Eurostat server were used: Gross domestic product, public debt, public deficit, public debt interest costs and inflation. All other values were calculated according to the equations mentioned above. For all the Eurostat data, the ESA95 methodology was 
applied. The simulations were performed in a standard spreadsheet application. The following Table 1 presents a list of the Eurostat data that were used for the simulation. Since Eurostat does not provide data on GDP at constant prices for the whole period 1995-2012, we used data from United Nation Data - GDP by Type of Expenditure at constant (2005) prices - National currency. UN Data uses the very same methodology for GDP calculation as Eurostat.

\section{Results}

The main results are shown in the following Figure 1. The dark column reveals the amount of debt in 1995 and the hatched column shows the change in the amount of debt up to 2012. The black indicator A1 (the values on the secondary axis) indicates the effect of failure to comply with the SGP rules to change the level of debt. In other words, it shows the difference in the level of debt in 2012 in the situation, where states would implement a responsible fiscal policy in the sense that is modeled in this article, and the level of real debt in 2012. The states in the chart are sorted according to this indicator. All the values are given as a percentage of GDP.

Figure 1 Values for Debt, Change in Debt and A1 Indicator of EU Member Countries (\% of GDP)

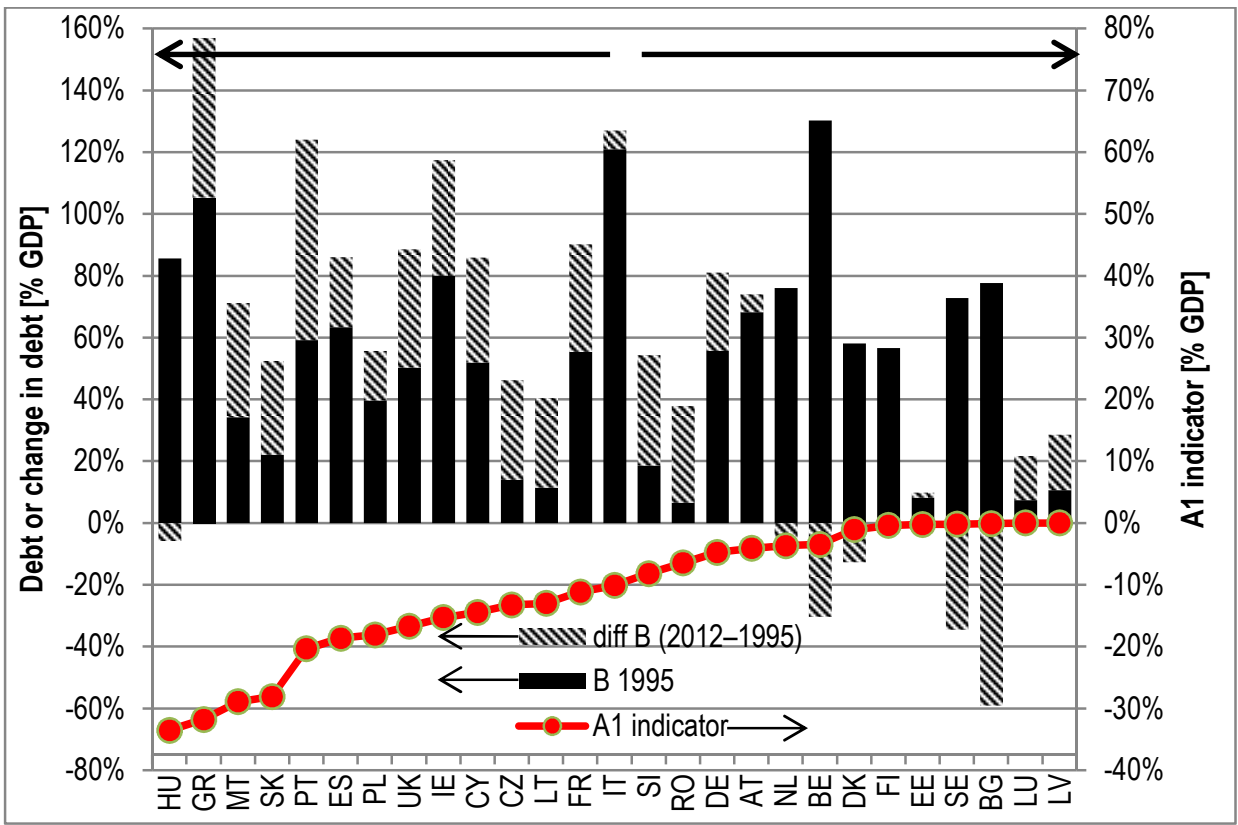

Source: Own calculations.

The indicator A1 shows the effect of non-compliance with the agreed rules on the increase in the debt level. The value of the A1 indicator for the countries following a responsible budget is close to $0 \%$ of GDP (the countries on the right of the chart). Alt- 
hough these states more or less complied with the rule of not exceeding the government deficit of $3 \%$ in the reference period, the level of debt reduction did not have to be significant. The reason is that these states did not have to exert adequate fiscal effort in terms of reducing the deficit further below $3 \%$ of GDP in the reference period. Between 1995 and 2012, these countries showed either a decrease in the level of public debt, if the initial debt was above $60 \%$ of GDP, or moderate growth of debt, when their initial level of debt was below $60 \%$. Although these states more or less complied with the $3 \%$ rule in the period, the level of debt reduction to the accepted fiscal efforts of the governments of these countries was in order to cut the deficit further below 3\%. Germany and Austria represent an exception from the development on the right side of the chart. Throughout the period, Germany acted fiscally responsibly, while the public deficit was either below $3 \%$ of GDP or only slightly higher. The level of debt increased in extrabudgetary ways (through the SFA) by at least $14.1 \%$ of GDP. A similar evolution, only on a weaker scale, can be observed in Austria.

The left side of the chart shows countries that are more likely to break the rules agreed in the SGP. This fact is depicted by the indicator A1. As a result, an increase in the level of public debt between 1995 and 2012 was observed in these countries, with the exception of Hungary. In this group of countries, Italy and Hungary are worth noting. The latter country has seen, despite non-compliance with the SGP, a decrease in the level of public debt. Level of inflation and bounded interest cost of servicing public debt were important factors influencing the decreasing level of debt (despite a significant budget deficit). At the time when the average annual change in price level between 1996 and 2012 was $7.8 \%$, the deficit of public budgets consisted solely of interest costs on debt service. In real terms, however, their influence on the level of debt was neutralized by the rapidly growing nominal GDP. If the country had been able to maintain the deficit within the limits of the SGP, the level of debt would have been about $33 \%$ of GDP lower. Italy also achieved primary surpluses throughout the whole period followed; on the other hand, however, the average change in the real GDP for the last 17 years was around $0.6 \%$. If the GDP growth had decreased relative debt level in Hungary, in Italy this favourable factor did not react. With the level of the deficit slightly above $3 \%$ of GDP between 1995 and 2007, Italy managed to reduce the debt level from $120.9 \%$ to $103.3 \%$ of GDP. These efforts were thwarted by the arrival of the economic crisis, and as a consequence, the public debt sharply increased to the level of $127 \%$ of GDP by 2012. Overall, we can conclude that the failure to comply with the SGP (indicator A1) in these countries had a significant effect on the change in the level of public debt in the analysed period. A similar evolution can be observed in Spain and other Mediterranean countries.

If states apply a responsible budgetary policy, it is surprising that a greater part of them would face an increase in public debt; see Figure 2. The dark column shows the change in the debt from 1995 to 2012 providing that the states complied with the SGP rules. The hatched column shows the effect of failure to comply with the SGP rules to change the level of debt (A1 indicator). Together, these two columns show the change in the debt from 1995 to 2012. The red indicator (the values on the secondary axis) reveals the number of situations in which the application of a responsible fiscal policy between 1995 and 2012 would not necessitate compliance with the 3\% of GDP limit on the grounds of poor economic performance (the real GDP growth is below $0.75 \%$ of GDP). 
Figure 2 Change in the Debt (\% of GDP) and Exceptions Due to Negative GDP Growth in EU Member Countries

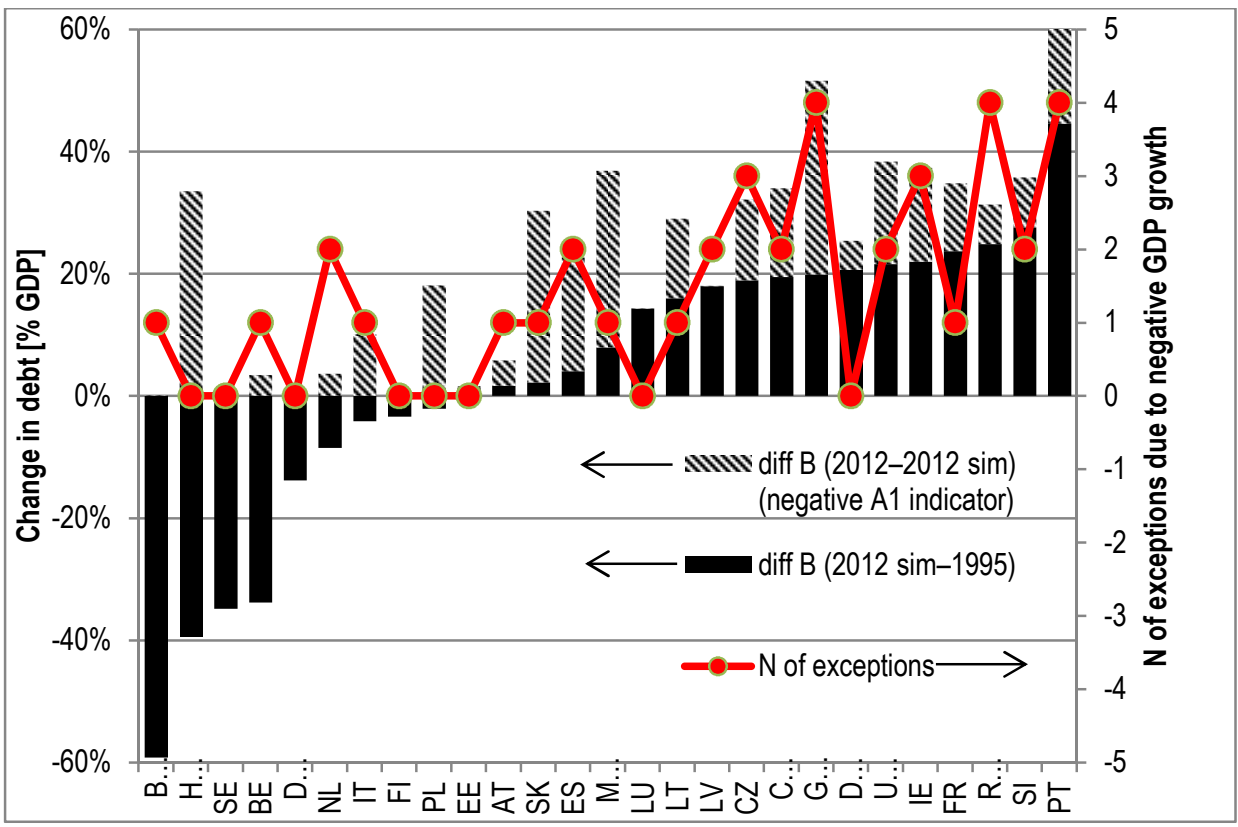

Source: Own calculations.

The figure shows that even with compliance with the SGP rules, the increase in the debt level is influenced by the number of exceptions in transactions given during the unfavourable economic development. This situation is well documented in the case of Spain which experienced economic decline in 2009-2012 (the data end in 2012). As a result, Spain could apply an exemption to keep the budget deficit below 3\% of GDP in 2009 and 2012. Therefore, the value of public deficit in these two years was above $10 \%$ of GDP and the debt in this period rose from $40.2 \%$ of GDP to $86.0 \%$ of GDP without this policy being assessed as fiscally irresponsible by the model (the evolution of the situation in Spain is well illustrated in the following Figure 3) in these two particular years. The situation is different in the case of Germany. Though our simulation showed the $3 \%$ as never having being exceeded, we can observe an increase in debt of $20.7 \%$ of GDP between 1995 and 2012. Here the situation is influenced by the existence of SFA. Between 2008 and 2012, German public debt increased by about 15\% of GDP. The existence of SFA explains most of the growth in debt change even with fiscally responsible policies. A different view on whether it is a fiscally responsible policy is proposed by Von Hagen and Wolff (2006, p. 3). They argue that: "SGP rules have induced governments to use stock-flow adjustments. This tendency is especially strong for situations when the cost of reducing the deficit is particularly large."

The previous Figure 2 showed a paradoxical situation in which even compliance with the rules of the SGP (but with the possibility of exceptions in times of economic downturn and the effects of SFA) would lead to a substantial decline in the level of debt only 
in Belgium (for euro area countries). Conversely, in most countries, the debt level increased. The previous example of Germany and Hungary has shown that this was mainly due to the development of public finances between 2008 and 2012. The following Figure 3 therefore decomposes the fiscally responsible policy between 1995 and 2012 into two periods, with the dividing year of 1997.

Figure 3 Decomposition of Debt Change (\% of GDP) Between 1995 and 2012 of EU Member Countries

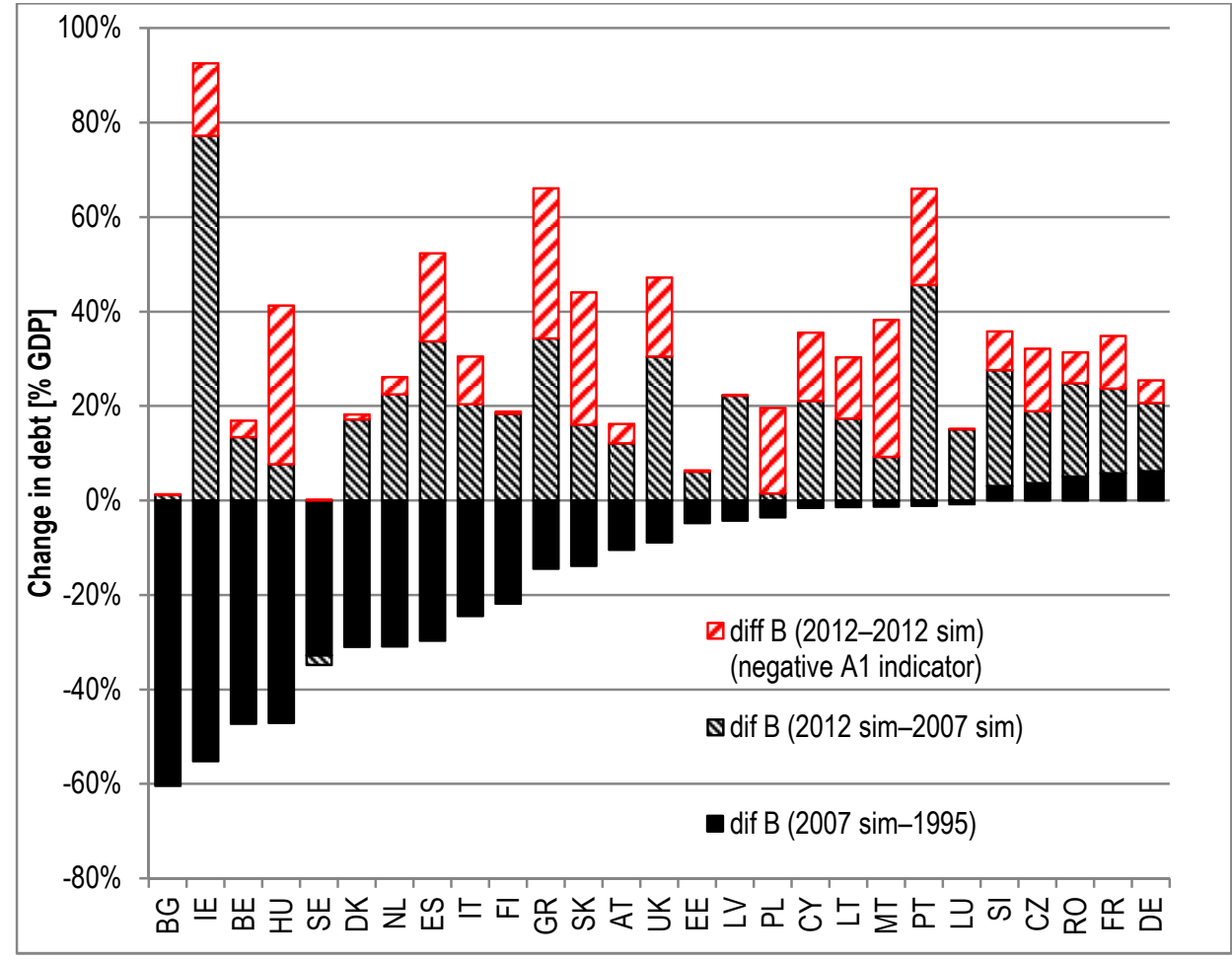

Source: Own calculations.

In the period after the entry into the euro area till 2007, compliance with the agreed rules in the vast majority of countries would lead to a decline in the level of public debt, or, as in the case of Germany and France, to a slight increase (dark column) only. The onset of the economic crisis and the associated exception in the following period until 2012 would lead to an increase in the level of public debt (the hatched column). The sum of all three values, together with the A1 indicator, then shows the total change in public debt between 1995 and 2012. Note the example of Ireland: Between 1995 and 2007 , it balanced public budgets or surpluses, with the result that the level of public debt declined from $80.1 \%$ of GDP to $24.9 \%$ of GDP. Due to the economic crisis and the fiscal measures to reduce the impact of the crisis, the level of debt in 2012 increased to $117.4 \%$ of GDP. 
Another interesting outcome of our model deals with implicit interest rates. Our calculation shows that the average implicit interest rate on public debt was still close to $8 \%$ in 1996 (see Figure 4).

Figure 4 The Average Implicit Interest Rate and Development of Values Corresponding to the Fifth and Ninety-fifth Percentiles

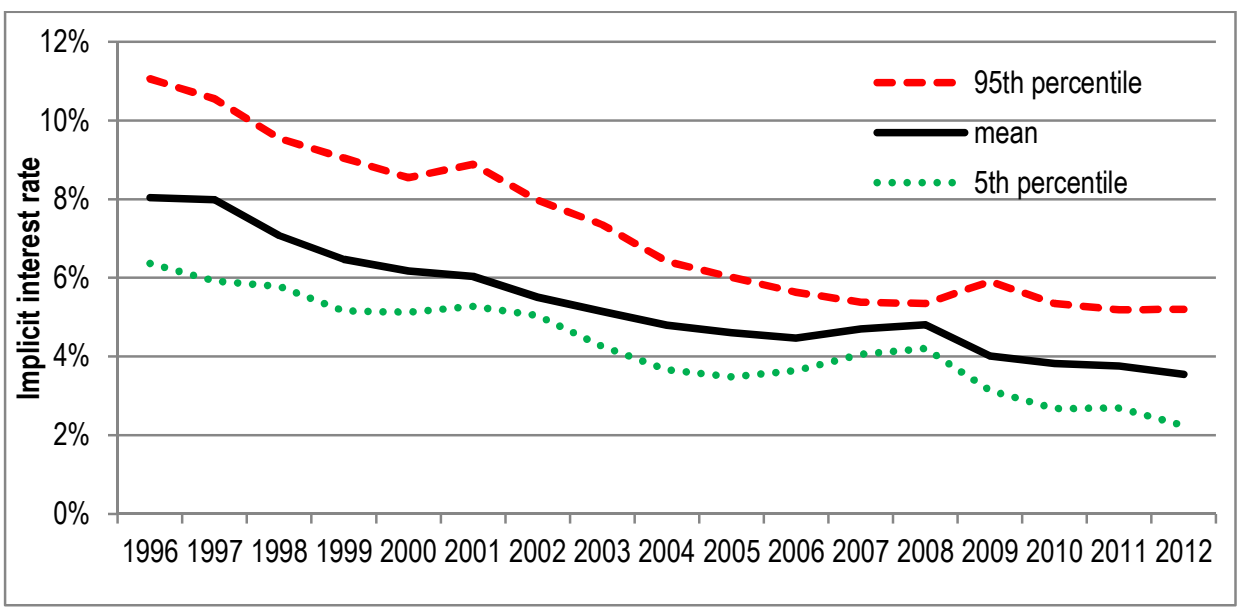

Source: Own calculations.

Along with the average public debt of around $60 \%$ of GDP, this meant that countries with higher levels of debt had to achieve primary surpluses to comply with the Maastricht convergence criteria for entry into the eurozone. Their settings - maximum 3\% deficit and $60 \%$ debt of GDP - were adopted with regard to the implicit interest rate on public debt to the amount of $5 \%$. One of the positive effects of the introduction of the common currency was the convergence of interest rates and their reduction to below $4 \%$. As the figure shows, the greatest degree of convergence was achieved in 2008; due to the financial and economic crisis, interest rates diverged more from that year onwards. The situation of lower interest cost and primary surpluses in the countries could be used to sharpen the reduction of fiscal imbalances. However, it turned out that one component of the deficit (interest costs) was continuously substituted by another component of the deficit (primary deficit). The ECB (2004, p. 41) argues that the low interest rates as a result of EMU entrance were used to increase primary spending and cut taxes.

\section{Conclusion}

The results of our previous research indicated that good intentions themselves are not sufficient to ensure good outcomes of budgetary policy. The rules of the Stability and Growth Pact allowed short-term deficit financing. In the medium term, public finances should be balanced; however, this never happened in most of the countries under observation. Even the application of the maximum allowable limit for the deficit was not observed by some states. According to our calculations, even if fiscally responsible 
policies had been followed between 1995 and 2012, we would observe an average increase in the level of public debt by $12 \%$ of GDP. The disrespect of the $3 \%$ rule caused an increase in the level of public debt of $8 \%$ of GDP in the reference period. We should also notice the influence of variable stock-flow adjustment, which in some countries was used to conceal the real state of public finances. The rules of the SGP were set simply and uniformly; decline in interest costs on public debt was one of the outcomes. Nevertheless, the countries were not forced to profit from this favourable situation and did not reduce their public deficit.

It should be noted that even occasional compliance violations resulted in a decrease in the debt level of most of the countries in the first period (until 2007). The greatest rate of debt growth occurred in the last 5 years when countries came to terms with the consequences of a prolonged economic crisis. While the model does not indicate that exceeding the permitted deficit of $3 \%$ of GDP should be a problem, from the perspective of public finance, a prolonged deficit of $6-10 \%$ of GDP is essential. It seems to us that this is a negative consequence of the low degree of attention that was paid to the condition of a balanced budget in the medium term. Therefore, the current efforts to link the SGP rules with the structural component of the deficit seem logical.

If we summarize what has been mentioned above, we must conclude that the actual setting of the SGP does not guarantee adequate decrease or stabilization in the level of public debt. This effect was further enhanced by non-compliance with the agreed rules both by member states and by the European Commission, and respectively by representatives of ECOFIN, who did not call for enforcement in respect of the SGP.

\section{References}

AFONSO, A. (2005). Fiscal Sustainability: The Unpleasant European Case. Finanzarchiv. 61(1), pp. 19-44.

AFONSO, A., RAULT, C. (2010). What Do We Really Know about Fiscal Sustainability in the EU? A Panel Data Diagnostic. Review of World Economics. 145(4), pp. 731755.

ALESINA, A., GIAVAZZI, F. (2002). Europe's Destabilizing Stability Pact. Project Syndicate. Retrieved February 5, 2014, from http://www.projectsyndicate.org/commentary/ag8/English

BLANCHARD, O., CHOURAQUI, J.-C., HAGEMANN, R.P., SARTOR, N. (1990). The Sustainability of Fiscal Policy: New Answers to an Old Question. OECD Economic Studies. $15 . \quad$ Retrieved November 5, 2013, from http://www.oecd.org/eco/outlook/34288870.pdf

BUITER, W. (2006). The "Sense and Nonsense of Maastricht" Revisited: What Have we Learnt about Stabilization in EMU? Journal of Common Market Studies. 44(4), pp. $687-710$.

BUTI, M., EIJFFINGER, S., FRANCO, D. (2003). Revisiting the Stability and Growth Pact: Grand Design or Internal Adjustment? European Economy - Economic Papers No. 180 (ISBN 92-894-4917-9). 
BUTI, M., MARTINOT, B. (2000). Open Issues in the Implementation of the Stability and Growth Pact. National Institute Economic Review. 174, pp. 92-104.

CALMFORS, L. (2005). What Remains of the Stability Pact and What Next? SIEPS Reports, No. 8. Swedish Institute for European Policy Studies (ISBN 91-85129-31-3).

COLLIGNON, S. (2012). Fiscal Policy Rules and the Sustainability of Public Debt in Europe. International Economic Review [online]. 53(2), pp. 539-567.

COUDERT, V. (2013). On Currency Misalignments within the Euro Area. Review of International Economics. 21(1), pp. 35-48.

DE GRAUWE, P. (2003). The Stability and Growth Pact in Need of Reform. Centre for European Policy Studies. Retrieved February 5, 2014, from http//www.econ.kuleuven.ac.be/ew/academic/intecon/Degrauwe/PDG-

papers/Discussion_papers/Stability\%20and\%20Growth\%20Pact\%20CEPS\%202003.pdf

DUWICQUET, V., MAZIER, J., SAADAOUI, J. (2013). Désajustement de change féderalisme budgétaire et redistribution: Comment s'ajuster en union monétaire. Revue de l'OFCE. 1(127), pp. 57-96.

ECOFIN (2005). Council's Report on Improving the Implementation of the Stability and Growth Pact, 2005. Retrieved February 5, 2014, from http://www.eu2005.lu/en/actualites/documents_travail/2005/03/21stab/stab.pdf

ECB (2004). Monthly Bulletin. Retrieved February 5, 2014, from http://www.ecb.europa.eu/pub/pdf/mobu/mb200401en.pdf (ISSN 1725-2822).

ECB (2012). Monthly Bulletin. Retrieved February 5, 2014, from http://www.ecb.europa.eu/pub/pdf/mobu/mb201204en.pdf

EUROPEAN COMMISSION (1997a). Council Regulation (EC) No. 1467/97 of 7 July 1997 on Speeding Up and Clarifying the Implementation of the Excessive Deficit Procedure. Retrieved February 5, 2014, from http://eurlex.europa.eu/LexUriServ/LexUriServ.do?uri=OJ:L:1997:209:0006:0011:EN:PDF

EUROPEAN COMMISSION (1997b). Resolution of the European Council on the Stability and Growth Pact Amsterdam. Retrieved February 5, 2014, from http://eurlex.europa.eu/LexUriServ/LexUriServ.do?uri=CELEX:31997Y0802\%2801\%29:EN:HT ML

EUROPEAN COMMISSION (2012). Treaty on Stability, Coordination and Governance Signed. European Council. Retrieved February 5, 2014, from http://www.europeancouncil.europa.eu/home-page/highlights/treaty-on-stability,-coordination-andgovernance-signed?lang=en

EUROPEAN COMMISSION (2013). Making it Happen: The European Semester. Retrieved February 5, 2014, from http://ec.europa.eu/europe2020/making-it-happen/

EUROPEAN UNION LAW (2011). The Pact for the Euro: A Summary. Retrieved February 5, 2014, from http://eulaw.wordpress.com/2011/03/13/the-pact-for-the-euro-asummary/ 
EUROSTAT (2013). The Main Factors Contributing to Changes in Government Debt Other than Government Deficits/Surpluses (Stock-Flow Adjustment). Retrieved February 5, 2014, from http://epp.eurostat.ec.europa.eu/cache/ITY_PUBLIC/STOCK_FLOW_2013_APR/EN/S TOCK_FLOW_2013_APR-EN.PDF

FISCHER, J., JONUNG, L., LARCH, M. (2006). 101 Proposals to Reform the Stability and Growth Pact. Why So Many? A Survey. European Economy - Economic Papers, No. 267 (ISBN 92-79-03843-5).

HAUPTMEIER, S., SANCHEZ FUENTES, J., SCHUKNECHT, L. (2010). Towards Expenditure Rules and Fiscal Sanity in the Euro Area. European Central Bank working paper series. Retrieved February 5, 2014, from http://www.ecb.europa.eu/pub/pdf/scpwps/ecbwp1266.pdf (ISSN 1725-2806).

IZÁK, V. (2009). Primary Balance, Public Debt and Fiscal Variables in Postsocialist Members of the European Union. Prague Economic Papers 2/2009.

SCHUKNECHT, L., MOUTOT, P., ROTHER, P., STARK, S. (2011). The Stability and Growth Pact: Crisis and Reform. European Central Bank occasional paper series, No. 129.

STOIAN, A. (2011). A Retrospective Approach on Assessing Fiscal Vulnerability: Empirical Evidence for Overindebted European Countries. Timisoara Journal of Economics. 4(3(15)), pp. 183-188.

STOIAN, A., ALVES, R. (2012). Can EU High Indebted Countries Manage to Fulfill Fiscal Sustainability? Some Evidence from the Solvency Constraint. FEP working papers. Retrieved February 5, 2014, from http://wps.fep.up.pt/wps/wp464.pdf

VAN DEN NOORD, P. (2010). Turning the Page? EU Fiscal Consolidation in the Wake of the Crisis. Empirica. 38(1), pp. 19-51.

VAN NIEUWENHUYZE, C. (2013). Debt, Assets and Imbalances in the Euro Area. Revue de l'OFCE. 1(127), pp. 123-152. Retrieved February 5, 2014, from http://www.cairn.info/revue-de-l-ofce-2013-1-page-123.htm

VON HAGEN, J., WOLFF, G.B. (2006). What Do Deficits Tell Us about Debt? Empirical Evidence on Creative Accounting with Fiscal Rules in the EU. Journal of Banking \& Finance. 30(12), pp. 3259-3279.

WENZEL, H.-D., LACKENBAUER, J., BRÖSAMLE, K.J. (2004). Public Debt and the Future of the EU's Stability and Growth Pact. Working paper no. 50. Germany: Bamberg University. Retrieved February 5, 2014, from http://www.unibamberg.de/fileadmin/uni/fakultaeten/sowi_lehrstuehle/vwl_finanzwissenschaft/DAADProjekt/Publikationen/pberg50.pdf 